\title{
Current situation and perspectives regarding human Chagas disease in midwestern of the state of Minas Gerais, Brazil
}

\author{
Christiane Santos Matos ${ }^{1 /+}$, José Eloy dos Santos Júnior', \\ Fernanda Alvarenga Cardoso Medeiros², Eliana Furtado², João Carlos Pinto Dias ${ }^{1,3}$ \\ 'Laboratório de Triatomíneos e Epidemiologia da Doença de Chagas, Centro de Pesquisa René Rachou-Fiocruz, \\ Belo Horizonte, MG, Brasil ${ }^{2}$ Laboratório de Parasitologia, Fundação Ezequiel Dias, Belo Horizonte, MG, Brasil \\ ${ }^{3}$ Posto Avançado de Pesquisas Emmanuel Dias, Bambuí, MG, Brasil
}

\begin{abstract}
Recognising the importance of Chagas disease in Brazil, Bambui set up epidemiological surveillance for Chagas disease in 1974 and was the first municipality to do so. To ascertain the current epidemiology of Chagas disease in this municipality, 1.782 blood samples from the general population were analysed; $7.7 \%$ of samples were found to be seropositive for Chagas disease. A strong positive correlation between increasing age and Chagas disease was evident in both genders, with the highest prevalence in individuals aged over 60 years. Clinically, the cardiodigestive form of Chagas disease was the most common in these samples. These data confirm the interruption of Trypanosoma cruzi transmission, in parallel with a still important residual morbidity of Chagas disease in the county, thus supporting political decisions that will prioritise epidemiological surveillance and medical treatment of Chagas disease in the coming years.
\end{abstract}

Key words: Bambuí - Chagas disease - seroprevalence

Chagas disease is an infection caused by the protozoan Trypanosoma cruzi (Chagas 1909), which can be transmitted to humans in various ways, such as through infected bugs (Insecta, Hemiptera, Reduviidae), via a congenital route or through a blood transfusion. Chagas disease is an important medical and social problem in many Latin American countries and is associated with significant morbidity and mortality. In Brazil, according to the National Serologic Survey conducted from 1975-1980, the states with the highest rates of prevalence were Rio Grande do Sul, Minas Gerais (MG), Bahia (BA) and Goiás. Currently, the prevalence of Chagas disease in these states remains significant, especially among the elderly (Ostermayer et al. 2011). Approximately 1.5-2 million people in Brazil are infected with $T$. cruzi and $20 \%$ of the population are at risk of acquiring the infection (Rassi Jr et al. 2010).

MG has historical significance in the study of Chagas disease, with high rates of morbidity and mortality over the past eight decades. Currently, it is estimated that there are approximately 600 thousand infected individuals living in the state. In parallel, MG remained infested with important household triatomine vectors for several decades, chiefly before 1980 (Gontijo et al. 2009, Silveira 2011).

The recent history of Chagas disease control started in the late 1940s in Bambuí, a western municipality of MG, with the discovery of 25 acute cases of Chagas dis-

doi: 10.1590/0074-0276130385

Financial support: FAPEMIG, CNPq, CPqRR-Fiocruz

+ Corresponding author: csmatos@ymail.com

Received 30 July 2013

Accepted 17 December 2013 ease and the first trials of effective insecticides against domestic triatomines. Since 1943, under the leadership of Emmanuel Dias, the Center for the Study and Prevention of Chagas Disease, now the Emmanuel Dias Research Center (PAEED), has published numerous studies related to the clinical diagnosis, epidemiology, treatment and control of vectorial transmission of T. cruzi infection and others. Insecticide campaigns conducted between 19441958 by the PAEED contributed to the reduction of the household vector, leading to the disappearance of cases of acute Chagas disease in urban and suburban areas of Bambuí (Dias 1945, 1982). The model developed by the PAEED served as the basis for the Chagas Disease Control Program carried out by the Superintendence of Public Health Campaigns (Vinhaes \& Dias 2000). In 1974, Bambuí was the first Brazilian municipality to implement epidemiological surveillance with community participation (Dias \& García 1978, Dias \& Dias 1985). In spite of the success of the vector control program, Bambuí still stands out among the other MG municipalities as one of the areas of greatest morbidity and mortality for Chagas disease, which are today restricted to adult and elderly populations (Dias 2009, Lima-Costa et al. 2010).

Given the historical importance of Chagas disease in Bambuí, a clinical and epidemiological study of the disease was conducted in the county to evaluate the impact of Chagas disease control activities and contribute to the current management of the disease in endemic areas.

The municipality of Bambuí is located in midwestern $\mathrm{MG}$, in a region called the Campos das Vertentes $\left(20^{\circ} 00^{\prime} 21^{\prime \prime} \mathrm{S} 45^{\circ} 58^{\prime} 37^{\prime \prime} \mathrm{W}\right)$, and is $270 \mathrm{~km}$ from the capital, Belo Horizonte (Fig. 1). It has an area of 1,455,82 $\mathrm{km}^{2}$, comprising approximately 22.734 inhabitants (IBGE 2010). Bambuí is currently divided into 203 localities, of which 179 (88\%) are rural, and its economy is based on milk, coffee, rice, corn, soybeans and sug- 
arcane. A cross-sectional study was conducted from February 2011-March 2012 in the resident population, in users from the Municipal Unique Health System and in residents of rural areas where household triatomine detection had occurred between 2004-2010. Every study participant had to (i) sign a consent form (National Committee in Ethical Research/Brazilian Ministry of Health, register 0008.0.245.000-09), (ii) register personal data (address, nationality, date of birth and gender) and (iii) permit a blood sample collection $(3 \mathrm{~mL})$ for serological analysis according to established protocols. The samples

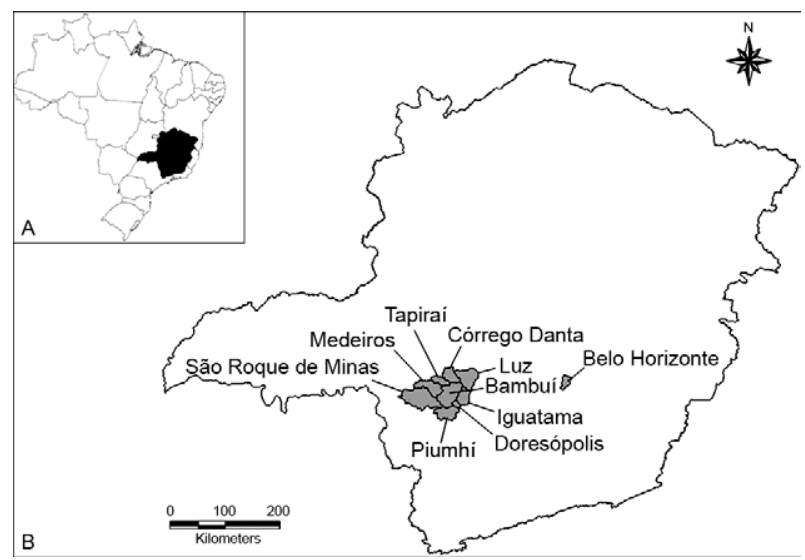

Fig. 1: Brazil map highlighting the state of Minas Gerais (MG) (A) and MG map showing Bambuí location and its neighbouring municipalities, referring to the capital Belo Horizonte (B). were tested by the Laboratory of Parasitology of the Ezequiel Dias Foundation (Belo Horizonte) for anti-T. cruzi IgG antibodies using an enzyme immunoassay (ELISA) $\left(\right.$ BioManguinhos $\left.^{\circledR}\right)$, indirect haemagglutination-inhibition (BioMérieux) and indirect immunofluorescence (IFI) (BioManguinhos). Any samples found to be positive in at least two serological reagent tests were retested to confirm the result. All the data were tabulated (Excel 2010) and analysed statistically (BioEstat v.5.0 - Windows ${ }^{\circledR}$ ) using the chi-square test and the Pearson correlation ( $\mathrm{p}<0.05$ and $95 \%$ confidence interval).

A sample size of 393 individuals was calculated using $\mathrm{n}_{0}=1 / \mathrm{E}^{2}$ and $\mathrm{S}=\mathrm{N} . \mathrm{n}_{0} / \mathrm{N}+\mathrm{n}_{0}$ [where $\mathrm{n}_{0}=$ initial sample, $\mathrm{E}=$ margin of error (5\%), $\mathrm{S}=$ sample and $\mathrm{N}=$ population]. Serum samples were collected from 1,782 Bambuí residents, of whom 1,376 (77.2\%) were natives of this municipality, $175(9.8 \%)$ were from neighbouring municipalities, $165(9.3 \%)$ were from other MG municipalities and $66(3.7 \%)$ were from other federal units. Women represented $62.8 \%(1,119 / 1,782)$ of the study population and men $37.2 \%(663 / 1,782)$. The study sample was considered representative of the municipality, covering 49\% (99/203) of the municipal localities (all urban localities and 75 rural localities). Individuals in the study were aged between four-99 years, with a median of 49 years (average $=48 \pm 18.5$ ). The 138 samples positive for anti-T. cruzi antibodies represented an overall prevalence of $7.7 \%$ chagasic infection, with no significant difference between genders $(51)$ and $87 \%, \mathrm{X}^{2}=$ $0.004, p=0.94$ ) (Table I). In both genders, the positive samples were in individuals aged over 60 years, except for two women under the age of 45 (Fig. 2). The most

TABLE I

Number of patients with positive serology for Trypanosoma cruzi according to place of birth, gender and age group obtained in a serological survey conducted in the municipality of Bambuí, state of Minas Gerais (MG), Brazil

\begin{tabular}{|c|c|c|c|c|c|c|c|c|c|c|}
\hline & \multirow[b]{2}{*}{ Place of birth } & \multirow{2}{*}{$\begin{array}{l}\text { Individuals } \\
\mathrm{n}(\%)\end{array}$} & \multirow{2}{*}{$\begin{array}{l}\hat{\sigma} \\
(\mathrm{n})\end{array}$} & \multirow{2}{*}{$\begin{array}{l}q \\
\text { (n) }\end{array}$} & \multicolumn{6}{|c|}{$\begin{array}{l}\text { Individuals by age group (in years) } \\
\qquad \text { (n) }\end{array}$} \\
\hline & & & & & $30-39$ & $40-49$ & $50-59$ & $60-69$ & $70-79$ & 80 and $>$ \\
\hline Municipalities & Bambuí & $106(76.82)$ & 42 & 64 & 1 & 4 & 10 & 41 & 35 & 15 \\
\hline \multirow{8}{*}{$\begin{array}{l}\text { Neighbouring } \\
\text { municipalities }\end{array}$} & Medeiros & $10(7.26)$ & 1 & 9 & - & - & - & 4 & 6 & - \\
\hline & Iguatama & $6(4.35)$ & 2 & 4 & - & 1 & 2 & 1 & 1 & 1 \\
\hline & Córrego Danta & $4(2.90)$ & 2 & 2 & - & - & - & 1 & 2 & 1 \\
\hline & Tapiraí & $3(2.18)$ & 1 & 2 & - & - & - & 2 & 1 & - \\
\hline & Doresópolis & $2(1.45)$ & 1 & 1 & - & - & - & 2 & - & - \\
\hline & Luz & $1(0.72)$ & 1 & - & - & - & - & - & 1 & - \\
\hline & Piumhí & $1(0.72)$ & 1 & - & - & - & - & 1 & - & - \\
\hline & São Roque de Minas & $1(0.72)$ & - & 1 & - & - & - & 1 & - & - \\
\hline \multirow{3}{*}{$\begin{array}{l}\text { Other MG } \\
\text { municipalities }\end{array}$} & São Pedro da Ponte Firme & $1(0.72)$ & - & 1 & - & - & - & 1 & - & - \\
\hline & Janaúba & $1(0.72)$ & - & 1 & - & 1 & - & - & - & - \\
\hline & Monte Carmelo & $1(0.72)$ & - & 1 & - & - & - & 1 & - & - \\
\hline $\begin{array}{l}\text { Other } \\
\text { federal units }\end{array}$ & Espírito Santo & $1(0.72)$ & - & 1 & - & - & - & 1 & - & - \\
\hline Total & & $138(100)$ & 51 & 87 & 1 & 6 & 12 & 56 & 46 & 17 \\
\hline
\end{tabular}


frequently observed clinical form of Chagas disease was the cardiodigestive form (Table II). There was a strong positive correlation between age and Chagas disease in both men $(r=0.75, p=0.008)$ and women $(r=0.73, p=$ 0.01 ). There was a higher number of both false negatives and false positives in the haemagglutination test than in either the ELISA or IFI tests (Table III).

The number of $T$. cruzi seropositive individuals in the study reflects the impact of the vector control programme performed regularly in Bambuí since the 1950s and the Chagas disease surveillance initiated in 1974. Historical data reported overall prevalence rates above $50 \%$ in the 1940s and 1950s, with individuals infected from early childhood, in contrast with the current survey (Dias \& Brant 1952, Dias 1982). Control activities, started in 1955 and covering the whole municipality, immediately resulted in the disappearance of acute cases and was followed by a gradual reduction in chronic cases at low ages (Dias 1974). These data (Dias 1974) strongly suggest that vectorial transmission of Chagas disease was halted in the late 1960s. Similar data have been recorded in the state of São Paulo (SP) since the 1970s, through systematic serological surveys of populations in areas undergoing vector control programmes, with striking reduction of $T$. cruzi seropositivity in younger individuals (de Souza et al. 1984). According to the PAEED records, the last acute case of Chagas disease was diagnosed in Bambuí in 1969, just prior to the establishment of the surveillance work in the municipality. In spite of more general factors, such as demographic emptying of the countryside and a progressive reduction of poor quality rural housing, the main determinant in reducing the Chagas disease prevalence in Bambuí must be considered to be due to the fumigation programme begun in the 1940s and optimised in the following decades. According to previously published data, Bambuí was virtually free of domestic triatomines

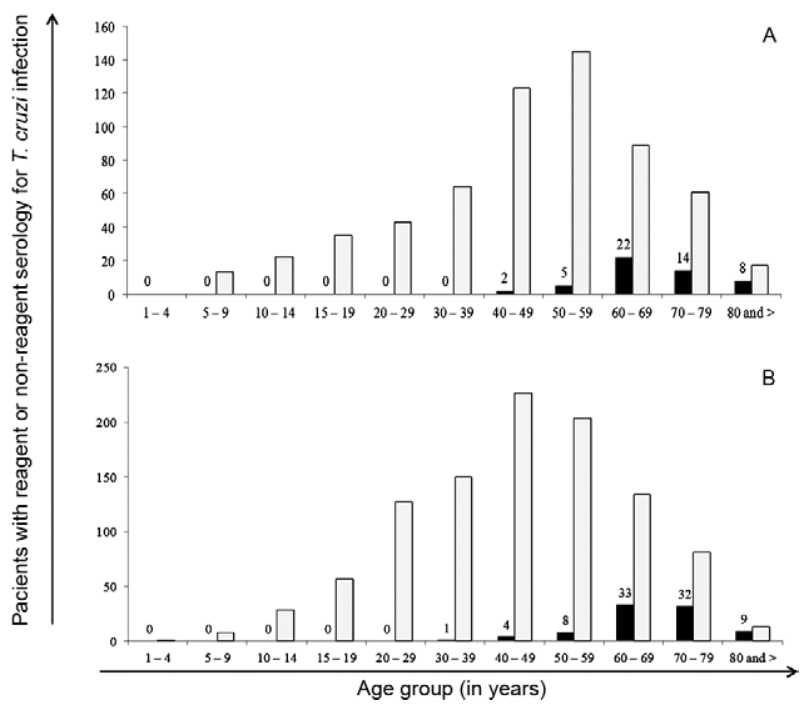

Fig. 2: number of seropositivity for Trypanosoma cruzi of men (A) and women (B) according to age group. The gray bars indicate negative results and the black positive serology. between 1957-1961, especially after a widespread purge carried out between 1956-1958; Triatoma infestans was last detected in Bambuí in 1977 (Dias 1982). Since the beginning of 1970, the population of T. infestans has decreased drastically throughout Brazil, with only occasional residual foci in BA (Silveira 2011). Following the control of this triatomine, native (autochthonous) species such as Panstrongylus megistus, Triatoma brasiliensis, Triatoma pseudomaculata, Triatoma sordida, Triatoma rubrovaria, Rhodnius neglectus and Rhodnius nasutus can occasionally invade the domestic environment and even begin small colonies (Forattini 1980, Schofield 1984). The existence of P. megistus in Bambuí's natural environment may result in the eventual invasion of domestic ecotopes by adult all over the municipality, mainly during the warmer months of the year. Since 1974, notifications of this triatomine have progressively declined, ranging from $80-90$ in the early years, to between $15-25$ of annual reports in the last seven years (Villela 2008, Dias 2009). These domestic captures are usually of adult insects, most likely originating from sylvatic ecotopes within the vicinity of the house; these insects could colonise both the intradomiciliary and peridomiciliary environments if the focus is not detected and eliminated (dos Santos Júnior et al. 2011). The reduction in the prevalence of human infections of T. cruzi after the effective control of household vectors was predicted by Emmanuel Dias in 1957 and was observed through seroepidemiological surveys in 1965, 1974 and 1980. This reduction is consistent with the reduction observed in SP from 1968 (Dias 1959, Silva-Rocha 1979, de Souza et al. 1984). Currently, the transmission of human Chagas disease has virtually disappeared in Bambuí. In parallel with vector prophylaxis, effective control of the few blood transfusions that occur in the municipality (by the official system of the Foundation Center of Hematology of the State of Minas Gerais) and virtual disappearance of congenital transmission of Chagas disease (because of the absence of infection in women of childbearing age) have been observed in Bambuí (Gontijo et al. 2009, Moraes-Souza \& Ferreira-Silva

TABLE II

Classification of patients according to Chagas disease clinical form

\begin{tabular}{lccc}
\hline & \multicolumn{3}{c}{ Gender } \\
\cline { 2 - 4 } Clinical form & $\begin{array}{c}\text { Female } \\
\mathrm{n}(\%)\end{array}$ & $\begin{array}{c}\text { Male } \\
\mathrm{n}(\%)\end{array}$ & $\begin{array}{c}\text { Total } \\
\mathrm{n}(\%)\end{array}$ \\
\hline Indeterminate & $6(8.82)$ & $8(24.24)$ & $14(13.86)$ \\
Digestive & $7(10.29)$ & $0(0)$ & $7(6.93)$ \\
Cardiac & $20(29.41)$ & $10(30.30)$ & $30(29.70)$ \\
Cardiodigestive & $35(51.47)$ & $15(45.45)$ & $50(49.50)$ \\
\hline Total & $68(100)$ & $33(100)$ & $101(100)$ \\
\hline
\end{tabular}

this work still have 37 patients (19 women and 18 men) who did not attend the clinical consultation. 
TABLE III

Performance of serological tests for evaluation by Trypanosoma cruzi infection in the general population sampled in the municipality of Bambuí, state of Minas Gerais (MG), Brazil

\begin{tabular}{|c|c|c|c|c|c|c|c|}
\hline \multirow{2}{*}{$\begin{array}{l}\text { ELISA } \\
\mathrm{n}(\%)\end{array}$} & & \multicolumn{3}{|c|}{$\begin{array}{c}\text { Indirect immunofluorescence } \\
\mathrm{n}(\%)\end{array}$} & \multicolumn{3}{|c|}{$\begin{array}{l}\text { Haemagglutination-inhibition } \\
\mathrm{n}(\%)\end{array}$} \\
\hline & & $\mathrm{R}$ & NR & IND & $\mathrm{R}$ & NR & IND \\
\hline $\mathrm{R}$ & $139(7.8)$ & $125(89.9)$ & $12(8.6)$ & $2(1.4)$ & $130(93.5)$ & $9(6.4)$ & - \\
\hline NR & $1,639(92)$ & - & $1,638(99.9)$ & $1(0.06)$ & $21(1.28)$ & $1,617(98.6)$ & $1(0.06)$ \\
\hline IND & $4(0.2)$ & - & $3(75.0)$ & $1(25.0)$ & $2(50.0)$ & $2(50.0)$ & - \\
\hline
\end{tabular}

$\mathrm{n}=1,782$. IND: indeterminated; NR: non-reagent; R: reagent.

2011, Ostermayer et al. 2011). A more detailed investigation of the Chagas disease transmission in the two $<45$ year-old women in this study who were infected with $T$. cruzi discovered that their mothers had Chagas disease. This indicates that congenital transmission may have occurred, because there were no reports of triatomine bugs, blood transfusion or oral infection. According to Dias (1982), the last reported case of vectorial transmission in Bambuí occurred in 1968. One of the T. cruzi-infected younger women had two children; both children were tested for T. cruzi infection, with non-reagent serological results. The discordant results observed were expected. We followed the recommendations of the Brazilian Consensus in Chagas Disease (MS 2005) for the interpretation of results: every individual had to have at least two positive serological results to be considered infected with T. cruzi. The present investigation revealed a significant residue of human Chagas disease in individuals who were certainly infected many years previously. In this context, the large number of patients with the cardiodigestive form of Chagas disease was expected. Due to the success of the vector control programme and no antecedent transfusions, it is believed that these two cases of Chagas disease in younger women were due to congenital infection, as the PAEED records showed that their mothers were $T$. cruzi seropositive. Ethically, the infected individuals need follow-up medical care consisting of parasitology and clinical investigations, electrocardiographic and radiological examinations, as well as supportive and specific treatment where appropriate. As the next step in this survey, this medical care is in the final review stage and will be the subject of further publications.

\section{ACKNOWLEDGEMENTS}

The whole PAEED and Policlínica Maria Adélia Cardoso teams, for the important support in the field works and the laboratory analyzes.

\section{REFERENCES}

Chagas C 1909. Nova tripanozomiaze humana. Estudos sobre a morfolojia e o ciclo evolutivo do Schizotrypanum cruzi n. gen, n. sp., ajente etiolojico de nova entidade morbida do homem. Mem Inst Oswaldo Cruz 1: 11-80.

de Souza AG, Valério-Wanderley DM, Buralli GM, de Andrade JCR 1984. Consolidation of the control of Chagas disease vectors in the state of São Paulo. Mem Inst Oswaldo Cruz 79 (Suppl.): $125-131$.

Dias E 1945. Um ensaio de profilaxia de moléstia de Chagas, Ministério da Educação e Saúde/Departamento Nacional de Saúde/Instituto Oswaldo Cruz/Imprensa Nacional, Rio de Janeiro, 116 pp.

Dias E 1959. Profilaxia da doença de Chagas. J Bras Med 1: 939-954.

Dias E, Brant TC 1952. Inquérito sobre doença de Chagas realizado nas localidades de Pedra Branca e Sertãozinho, município de Bambuí, Minas Gerais. Rev Bras Malariol Doencas Trop 4: 227-230.

Dias JCP 1974. Perspectivas para o controle da doença de Chagas humana em área através de profilaxia domiciliar com inseticidas de ação residual. Experiência de Bambuí, Minas Gerais, Brasil, MsD Thesis, Universidade Federal de Minas Gerais, Belo Horizonte, 34 pp.

Dias JCP 1982. Doença de Chagas em Bambuí, Minas Gerais, Brasil: estudo clínico-epidemiológico a partir da fase aguda, entre 1940 e 1982, PhD Thesis, Universidade Federal de Minas Gerais, Belo Horizonte, $362 \mathrm{pp}$.

Dias JCP 2009. Longitudinal studies on human Chagas disease in Bambuí, Minas Gerais, Brazil. Rev Soc Bras Med Trop 42: 61-72.

Dias JCP, Dias RB 1985. Participação da comunidade no controle da doença de Chagas. Ann Soc Belg Med Trop 65 (Suppl. 1): 127-135.

Dias JCP, García ALR 1978. Vigilancia epidemiológica con participación comunitaria. Un programa de enfermedad de Chagas. Bol Oficina Sanit Panam 84: 533-544.

dos Santos Júnior JE, Diotaiuti L, Dias JCP 2011. First report of Panstrongylus megistus sylvatic focus in municipality of Bambuí, state of Minas Gerais, Brazil. Mem Inst Oswaldo Cruz 106: 510-513.

Forattini OP 1980. Biogeografia, origem e distribuição da domiciliação de triatomíneos no Brasil. Rev Saude Publica 14: 265-299.

Gontijo ED, Andrade GMQ, Santos SE, Galvão LMC, Moreira EF, Pinto FS, Dias JCP, Januário JN 2009. Triagem neonatal da infecção pelo Trypanosoma cruzi em Minas Gerais, Brasil: transmissão congênita e mapeamento das áreas endêmicas. Epidemiol Serv Saude 18: 243-254.

IBGE - Instituto Brasileiro de Geografia e Estatística 2010.Cidades@, Brasília. Available from: ibge.gov.br/cidadesat.

Lima-Costa MF, Peixoto SV, Ribeiro AL 2010. Chagas disease and mortality in old age as an emerging issue: 10 year follow-up of the Bambuí population-based cohort study (Brazil). Int J Cardiol 145: 362-363.

Moraes-Souza H, Ferreira-Silva MM 2011. O controle da transmissão transfusional. Rev Soc Bras Med Trop 44: 64-67. 
MS - Ministério da Saúde Brasil 2005. Consenso brasileiro em doença de Chagas. Rev Soc Bras Med Trop 38 (Suppl. 3): 7-29.

Ostermayer AL, Passos ADC, Silveira AC, Ferreira AW, Macedo V, Prata AR 2011. O inquérito nacional de soroprevalência de avaliação do controle da doença de Chagas no Brasil (2001-2008). Rev Soc Bras Med Trop 44: 108-121.

Rassi Jr A, Rassi A, Marin-Neto JA 2010. Chagas disease. Lancet 375: 1388-1402.

Schofield CJ 1984. Triatominae: biology and control, Euro Communicated, United Kingdom, 76 pp.
Silva-Rocha EO 1979. Profilaxia. In Z Brener, Z Andrade, Trypanosoma cruzi e doença de Chagas, Guanabara Koogan, Rio de Janeiro, p. 425-449.

Silveira AC 2011. O inquérito triatomínico (1975-1983). Rev Soc Bras Med Trop 44: 26-32.

Villela MM 2008. Vigilância entomológica da doença de Chagas na região centro-oeste de Minas Gerais, Brasil, $\mathrm{PhD}$ Thesis, Centro de Pesquisas René Rachou, Belo Horizonte, 162 pp.

Vinhaes MC, Dias JCP 2000. Doença de Chagas no Brasil. Cad Saude Publica 16: 7-12. 